\title{
CORRESPONDENCE
}

\section{APPLANATION TONOMETRY \\ USING ANAESTHETIC-FLUORESCEIN MIXTURE}

To the Editorial Committee of the British Journal of Ophthalmology

SIRS,-In your April issue (Brit. J. Ophthal., 1965, 49, 205) you published my paper "Applanation Tonometry using One Drop of an Anaesthetic-Fluorescein Mixture". This paper recommended a mixture containing 0.3 per cent. Novesine and 0.125 per cent. fluorescein; one drop gave good corneal anaesthesia and a good fluorescent ring for Goldmann applanation tonometry. Of the eight anaesthetic solutions tested, Novesine showed no precipitate when mixed with fluorescein at $37^{\circ} \mathrm{C}$.

A few weeks after this paper was published, A. Wander Ltd. re-formulated Novesine so that the currently available Novesine is incompatible with fluorescein, a dense precipitate being formed. This incompatibility is due to the addition to Novesine of chlorhexidine 0.009 per cent. as a bacteriostat. The new Novesine solution may form a precipitate with fluorescein in the conjunctival sac if there is any anaesthetic solution remaining when the fluorescein is added.

The Pharmacy Department of this hospital now make 0.4 per cent. Novesine solution for topical anaesthesia to their own formula. This solution is compatible with fluorescein. The resulting Novesine-fluorescein mixture contains no precipitate, is quick and efficient for applanation tonometry, and, having a $p \mathrm{H}$ of $6 \cdot 85$, it causes minimal discomfort to the patient.

The prescription for 0.4 per cent. Novesine is:

Crystalline Novesine powder

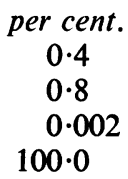

Sodium chloride $100 \cdot 0$

Aqua dist ad

Autoclave at $115^{\circ} \mathrm{C}$. for 30 minutes at $10 \mathrm{lb}$. pressure.
The $p \mathrm{H}$ of this solution is 5.0 .

The prescription for 0.5 per cent. fluorescein is given in my original paper; 0.4 per cent. Novesine and 0.5 per cent. fluorescein are mixed aseptically in a $3: 1$ ratio to give the final mixture.

I am grateful to you for allowing me this space to explain the situation. A. Wander Ltd. join me in apologizing to your ophthalmic and pharmaceutical readers for the sudden incompatibility of Novesine and fluorescein; happily, this is not irrevocable.

Yours faithfully,

\section{P. J. FENTON}

MoORFIELdS Eye Hospital,

CITY ROAD,

LONDON, E.C.1.

July 30, 1965.

\section{REFERENCES}

Fenton, P. J. (1964). Brit. J. Ophthal., 48, 633. (1965). Ibid., 49, 205. 